\title{
The Effects of Social Support, Trust and Social Presence on Social Commerce Intention: A Meta-Analysis
}

\author{
İlhami TUNCER*
}

\begin{abstract}
With the development of technology, social media platforms have become widespread and they have become suitable for use by consumers for different purposes. One of these purposes is the opportunity to shop on social media. The volume of social commerce worldwide has reached an important level and its development continues. Hence, interest in researching consumer behavior has increased in social commerce literature. There have been many studies in the literature on the relationships of social support, social presence, trust and social trade intention. From this point of view, the purpose of this study is to synthesize previous studies examining the relationship among the variables of social support, social presence, trust and social commerce intention in the framework of a single model with the meta-analysis method. In this context, the findings of 36 studies are synthesized with the meta-analysis method. According to the findings of this synthesis, it is determined that the variables of informational support, emotional support, trust in the social commerce site, trust in the vendor on the social commerce site and social presence significantly affect social commerce intention. These findings may provide researchers who will conduct studies on this topic in the future with significant contributions in terms of analyzing the scope of the literature and shaping their studies. Additionally, marketing managers in the sector may utilize these meta-analysis findings in determination of their marketing strategies.
\end{abstract}

Keywords: Social Support, Trust, Social Presence, Social Commerce Intention, Meta-Analysis

\section{Sosyal Destek, Güven ve Sosyal Varlığın Sosyal Ticaret Niyetine Etkileri: Bir Meta Analiz}

\section{ÖZ}

Teknolojinin gelişimiyle birlikte sosyal medya platformları yaygınlaşmaya başlamış ve tüketicilerin farklı amaçları için kullanımı uygun hale gelmiştir. bu amaçlardan biri de sosyal medya üzerinden alışveriş yapabilme imkanıdır. Dünya genelinde sosyal ticaretin hacmi önemli bir düzeye gelmiş ve gelişimi devam etmektedir. Dolayısıyla sosyal ticaret literatüründe tüketici davranışının araştırılmasına yönelik ilgi artmıştr. Literatürde sosyal destek, sosyal varlık, güven ve sosyal ticaret niyeti ilişkileri üzerine birçok çalışma yapılmıştır. Bu noktadan hareketle bu çalıșmanın amacı, sosyal destek, sosyal varlık, güven ve sosyal ticaret niyeti değişkenleri arasındaki ilişkiyi tek bir model çerçevesinde inceleyen önceki çalışmaları meta-analiz yöntemi ile sentezlemektir. Bu bağlamda 36 çalışmanın bulguları meta-analiz yöntemi ile sentezlenmiştir. Bu sentezin bulgularına göre, bilgi desteği, duygusal destek, sosyal ticaret sitesine güven, sosyal ticaret sitesinde satıcıya güven ve sosyal varlık değişkenlerinin sosyal ticaret niyetini önemli ölçüde etkilediği belirlenmiştir. Bu bulgular, gelecekte bu konuda çalışmalar yapacak araştırmacılara, literatürün kapsamını analiz etme ve çalışmalarını şekillendirme açısından önemli katkılar sağlayabilir. Ayrıca sektördeki pazarlama yöneticileri, pazarlama stratejilerinin belirlenmesinde bu meta-analiz bulgularından yararlanabilirler

Anahtar Kelimeler: Sosyal Destek, Güven, Sosyal Varlık, Sosyal Ticaret Niyeti, Meta Analiz

\section{Introduction}

With development of the Web 2.0 technology and the emergence and prevalence of social media in connection to this, the use of social commerce has increased and become popular (Fan et al., 2019). The use of social media platforms like especially WeChat, Instagram and Facebook in social commerce is highly prevalent. The platforms have provided significant contributions by transforming interactions, information accessibility and shopping experiences in e-commerce (Bugshan \& Attar, 2020; Hajli, 2015; Leung et al., 2019). This is because, while conventional e-commerce practices are more sale-oriented, social commerce platforms are more focused on social interaction and users (Fan et al., 2019; Liu et al., 2019; Zhang et al., 2014). Therefore, they may allow consumers to make a healthier decision by facilitating their interactions with other consumers who have purchased a similar product. At the same time, these properties allow consumers to share their shopping experience with social communities.

Such an increase in social commerce in practice has encouraged scientists to scientifically investigate this issue (Al-Tit et al., 2020; Hajli, 2015; Huang \& Benyoucef, 2015). In literature reviews, it may be

\footnotetext{
* Dr. Öğr. Üyesi, Karamanoğlu Mehmetbey Üniversitesi, ituncer@kmu.edu.tr
} Makalenin Gönderim Tarihi: 31.10.2020; Makalenin Kabul Tarihi: 12.04.2021 
observed that scientific research has increased towards the shopping behaviors conducted by consumers via social media. In particular, a large proportion of researchers are conducting studies for determining predictors that affect social commerce intention. Studies have generally investigated the relationship of social support, trust and social presence with social commerce intention (Al-Tit et al., 2020).

It has been emphasized in previous studies that trust is one of the most important antecedents that trigger the social commerce intention of consumers (Wang et al., 2016; Yahia et al., 2018). This is because consumers feel less safe in online channels in comparison to offline channels. Thus, the trust of the consumer is a precondition for social commerce intention (Pavlou, 2003). In the context of social commerce, there are studies investigating the relationship between the two (Bugshan \& Attar, 2020; Hajli, 2015; Sharma et al., 2019; Zhao et al., 2020). When we look at studies in the literature, it is seen that the construct of trust has been categorized based on the types of sources such as "trust in the platform" and "trust in the vendors". Other variables that are most frequently researched by scientists in the context of the antecedents of social commerce intention are social support and social presence. With the interpersonal communication and information sharing property of social media, consumers may provide social support. Therefore, the provided social support may become a significant instrument in influencing behavior (Ballantine \& Stephenson, 2011). In the context of social commerce, the construct of social support has been investigated by categorization as emotional support and informational support. Social presence is a situation that is related to consumers' perceptions of the presence of the elements they interact with on the social platform (Park \& Cameron, 2014). A high level of social presence may contribute to development of social commerce by increasing interaction (Gefen \& Straub, 2004a).

Several studies have been carried out towards the relationships among these constructs, but it is highly difficult to individually generalize these studies. Meta-analysis is a statistical method that compiles the findings of multiple independent studies (Zhao et al., 2018), and in comparison to conventional literature research, it may help researchers derive more reliable results (Schmidt \& Hunter, 2015). This study aimed to synthesize and generalize a single model on the relationships among social support, social presence, trust and social commerce intention based on the findings of previous studies by using the meta-analysis method. By preserving the multi-dimensional structure of especially the constructs of trust and social support, it was aimed to determine whether or not there was a difference in the weights of the effects of these on social commerce intention.

\section{Literature review and hypotheses development}

\subsection{Social support}

Evidence that the internet may provide consumers with social support has been revealed in studies in the literature (Obst \& Stafurik, 2010). This is because social support emerges with the interaction of online communities (Shanmugam et al., 2016). For example, Park et al. (2009) stated that one of the most important factors of the communication of consumers in online communities is provision of social support. Based on this point, it is revealed that reciprocal interaction and communication have a significant role in providing consumers with social support. Therefore, the development of the Web 2.0 technology may have significant contributions in achieving communication and interaction. For example, there is evidence in the literature that social media, which is a product of the Web 2.0 technology, makes the communication and interaction of communities easier (Liang et al., 2011). This shows that social media creates a significant source in providing consumers with social support (Lin et al., 2012).

Social support refers to social resources presented by individuals in social media channels or communities (Gottlieb \& Bergen, 2010). With a more detailed definition, it was expressed as "information leading the subject to believe that he is cared for and loved, esteemed, and a member of a network of mutual obligation" (Cobb, 1976, p. 300). In the SNS context, social support is defined as "the social resources that persons perceive to be available or that are actually provided to them by nonprofessionals in the context of both formal support groups and informal helping relationships" (Hajli, 2013, p. 146). The concept of social support has a multi-dimensional structure in different contexts as informational, emotional, tangible, evaluative and instrumental (House, 1981; Madjar, 2008; Schaefer et al., 1981; Xie, 2008). In the context of social commerce, consumers need various forms of intangible support such as general assessment information and help regarding products and services in purchasing processes. 
Therefore, based on this point, it is understood that, in the context of social commerce, the support needed by consumers is the informational and social support of other consumers (Coulson, 2005). Moreover, if studies in the literature in the context of social commerce are examined, it is observed that, as social media or online communities are in a virtual environment, the construct of social support has been designed on the basis of intangible aspects consisting of informational and emotional components. Thus, in the scope of this study, studies involving these two dimensions were included in the metaanalysis.

Emotional support is explained as an emotional and influential power provided to the consumer by other community members involving components such as compassion, love, understanding, courage and listening (Hajli et al., 2015; Ommen et al., 2008). As it would be understood from these components, emotional support may pave the way for formation of interactions of consumers with other group members by directly increasing the warmth in their heart (Lin et al., 2015). With this interaction, the existing concerns of the consumer in the purchasing process are revealed, and the indirect emotional support provided by their peers (Leong et al., 2020) may be useful in purchasing decisions (Fan et al., 2019). Informational support rather consists of practical and useful support including advice, guidance, comments and recommendations provided to consumers by their peers (Hajli et al., 2015b; Liang \& Turban, 2011). Informational support may provide usefulness for the consumer to obtain new opinions, solve their problems and therefore make purchasing decisions easier (Liang et al., 2011).

Positive communication taking place regarding a product or service may significantly contribute to the purchasing decisions of consumers (Naylor et al., 2012). In particular, especially with development of the Web 2.0 technology, social media has increased the interaction among consumers or peers, and therefore, allowed the prevalence of social support. This has made social media an important tool in shaping consumer behaviors (Tsai et al., 2012). Previous studies investigated the relationships between social support and social commerce intention (Lee \& Chen, 2020; Liang et al., 2011; Zhang et al., 2014). Huang et al. (Huang et al., 2020) conducted a study on hotel customers and revealed that, by mediation of social media, social support had a significant effect on social commerce intention. The emotional and informational support dimensions of social support also affect social commerce intention (Lal, 2017; $\mathrm{Li}$, 2019; Makmor et al., 2018). For example, Al-tit et al. (2020) concluded that informational and emotional support in the framework of social media affects social commerce intention. Therefore, we hypothesize:

H1. Emotional support is positively associated with social commerce intention.

H2. Informational support is positively associated with social commerce intention.

\subsection{Trust}

As the act of shopping involves interaction and communication, trust is a highly important key factor (Fukuyama, 1995). In particular, in the context of online transactions, previous studies have determined trust to be a significant factor (Eriksson et al., 2005). This is because on platforms where social order cannot be achieved, and there is high uncertainty like social media (Alshibly, 2015), trust may have a role in reducing complexity (Luhmann, 1979). For this reason, the factor of trust has been thoroughly investigated in the literature in the relationships of online consumer purchasing intention and vendor trust (Chen \& Shen, 2015; Wu et al., 2010).

The concept of trust has been defined in various ways as it has been studied commonly and prevalently by several disciplines. Schurr \& Oznne (1985) defined trust as “one's confidence in the exchange party's capability and willingness to establish the business' adherence to the relationship norms and keeping promises". Morgan \& Hunt (1994) explained as a collaboration between two parties where each party believes in the reliability and loyalty of the other. In the context of e-business, trust means the positive attitude of the consumer regarding the capacity of the vendor or supplier to meet the responsibilities they propose and their good intentions (Jones, 1999). More specifically, in the context of social commerce, trust was defined as positive expectation levels of social media users towards electronic retailers and suppliers and behavioral intentions regarding to what extent they resort to these retailers in the purchasing process (Yakimova et al., 2019). The consumer is fed by their peers on social media and their environment in the construction of this expectation and this behavioral intention (Lu et al., 2016). 
If we examine the literature regarding the concept of trust in the context of social commerce, it is observed that studies have focused on two different actors: trust in the vendor and trust in the social media platform. Therefore, in this study, too, the variable of trust was discussed on the basis of these two dimensions. It is accepted that trust is one of the most important determinants of purchasing intention as it keeps the risk perception of consumers on a certain level. Especially on social media platforms where the parties have limited information on each other, trust may become even more important (Lauterbach et al., 2009). Previous studies investigated relationships between trust and social commerce intention (Al-Tit et al., 2020; Dabbous et al., 2020; Hajli et al., 2017; Lu, Zeng, et al., 2016; Yahia et al., 2018). For example, in their study with consumers in developing markets, Gibreel et al. (2018) revealed that trust in the vendor on the Instagram platform had a positive relationship with social commerce intention. Similarly, in their study on consumers in the United Kingdom, Hajli (2015) concluded that trust in the social media platform had a positive relationship with social commerce intention. Accordingly, we propose:

H3. Trust in the vendor is positively associated with social commerce intention.

H4. Trust in the social media platform is positively associated with social commerce intention.

\subsection{Social presence}

It is observed that social presence is paid more importance in social commerce studies as it makes the communications and relations of customers on social media with each other easier (Friedrich et al., 2019; Lu et al., 2016; Shen, 2012). Social presence is a perceptual measure of the feeling of the individual regarding their psychological connection to their counterparts in a communication environment (Algharabat et al., 2018; Gefen \& Straub, 2004a). Based on this point, in the context of social commerce, social presence may be expressed as the degree to which consumers are able to establish warm, sincere, personal and social interactions with the vendor and other exchange partners on social media platforms and feed their presence. In other words, the non-verbal clues of the social media platform and its level of being able to reflect the warmth of the consumer's counterparts may be the determinant of the level of social presence (Ye et al., 2020).

The level of social presence is higher in environments where there is in-person communication in comparison to online environments. However, the level of social presence may also change based on the existing environmental conditions in online environments (Gefen \& Straub, 2004b). For example, while social presence is low on e-commerce sites due to the level of reciprocal interaction, it may be higher on social media platforms as they allow such an interaction. This is because social media has a channel structure that allows consumers to test presence by allowing them to interact with their counterparts (Wang \& Zhang, 2012). Moreover, Gefen \& Straub (2003) supported this by stating that contents such as personal photographs and messages shared in the digital environment may create high levels of social presence. Looking at the literature, it is observed that social support has been examined in one dimension or multiple dimensions. In this study, a one-dimensional examination was found appropriate due to the suitable number of studies on social presence as a single dimension for meta-analysis.

Social presence was accepted as an important predictor that affects consumers' social media usage intention as it allows them to perceive warmth and sensitivity from their counterparts (Cheung et al., 2011). Similarly, according to Zhang et al. (2014), high social presence may encourage consumers to share their commercial information and receive recommendations from other consumers on social media by increasing social interaction. In other words, social presence is an important antecedent that determines social commerce intention. There are studies in the literature which have examined the relationship between these two variables (Friedrich et al., 2019; Hajli et al., 2017; Zhang et al., 2014). For example, Soleimani (2019) revealed in their study that there was a positive relationship between the social presence perceptions of social media user university students and social commerce intentions. Accordingly, we hypothesize:

H5. Social presence is positively associated with social commerce intention.

Research model is illustrated in Figure 1; 


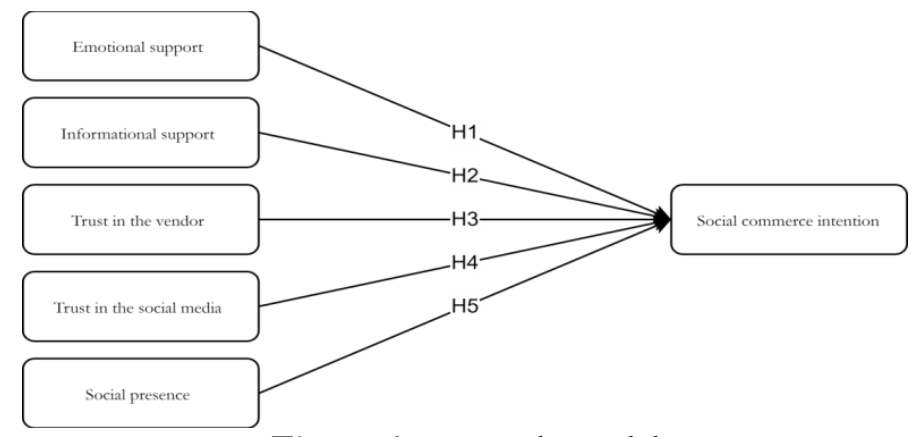

Figure 1. Research Model

\section{Method}

\subsection{Data collection}

The following steps were taken to determine studies in the literature regarding the relationships of social support, trust and social presence with social commerce intention for the meta-analysis and to apply the meta-analysis procedures in previous studies. First of all, studies were comprehensively searched by using search phrases as "social support" OR "trust" OR "social presence" OR "social commerce intention" on electronic databases as ScienceDirect, Emerald, EBSCO, SAGE, Taylor \& Francis, Google Scholar, Web of Science, ProQuest Dissertations \& Theses Global and International Conference on Information Systems (ICIS). Our study did not make any distinction based on the type of publication. This was because it was recommended that, to eliminate the suspicion of publication bias, meta-analysis studies should include all studies (journal and conference papers, $\mathrm{PhD}$ theses and unpublished manuscripts) (Ada et al., 2012). Additionally, failing to include, even by chance, non-article publications in a meta-analysis results in the "file drawer problem" (Rosenthal, 1991). This is because only including published studies may threaten the internal validity of meta-analysis studies (Ada et al., 2012). By scanning the aforementioned databases, firstly, 659 articles approximately related to this topic were accessed. Afterwards, among the articles, those unrelated to the topic, those that did not include an empirical study and those that did not report Pearson's correlation coefficients and sample sizes were filtered out. Finally, 36 studies were included in the meta-analysis.

\subsection{Meta-analysis procedure}

Meta-analysis is a highly reliable method of providing a literature summary regarding empirical studies (Hamari \& Keronen, 2017; Morris, 2007). It is a method that combines and quantitatively synthesizes the results of studies conducted on the subjects determined with this method. In this context, in this study, correlation coefficients in independent studies examining the relationship between social support, social presence, trust and social commerce intention were analyzed using meta-analysis method. In the first stage of the meta-analysis, the effect size was calculated based on the correlation value of each study. In metaanalysis, the effect size value predicts the magnitude of the relationship between certain variables (Borenstein et al., 2011). In the next step, heterogeneity test was applied. The interpretation of the heterogeneity test was based on Q-statistics and I² values (Hamari \& Keronen, 2017). Finally, publication bias test was applied. In this study, the problem of publication bias was avoided since all published or unpublished studies on this subject were included in the meta-analysis (Ada et al., 2012). However, in order to strengthen this situation, the publication bias test was conducted by examining the significance of the Tau coefficient. In the calculation of values such as effect size, heterogeneity, standard normal deviations (Z-value) and 95\% confidence intervals, the Comprehensive Meta-Analysis software was utilized. Additionally, in meta-analysis studies, there is a need for at least 3 different studies to be able to investigate the relationship between two variables (Kirca et al., 2005). For this reason, the relationships with more than three studies were included in the meta-analysis. 


\section{Analysis and findings}

In this study, by utilizing the meta-analysis of the relationship between trust, social support and social presence and social commerce intention, it was aimed to determine their combined effect. The fixed effects and random effects models may be used in calculating the effect size. While the fixed effects model assumes that there is a single effect in the population where the sample is taken from, the random effects model assumes that there are varying effect sizes in the population where the sample is taken from. In this study, the random effects model was preferred in the calculation of the effect size. This was based on the argument by Field \& Gillett (2010) that, due to the nature of data in the field of the social sciences, it is necessary to use the random effects model.

The findings of the meta-analysis conducted for the objective of this study are summarized in Table 1. This table presents the dependent and independent variables, mean correlation values, numbers of studies, p-values, Z-values and 95\% confidence intervals. Considering the p-value of the relationships between dependent and independent variables in Table 1, it is observed that H1, H2, H3, H4 and H5 hypotheses are accepted and there is a strong positive relationship. Compared to other hypotheses, there is a lower level of relationship between social presence and social commerce intention variables. The strongest relationship was between the trust in the vendor and social commerce intention variables. According to Hamari \& Keronen (2017), effect sizes are divided into three categories as strong (0.5), moderate (0.3) and weak (0.1). Based on this categorization, the vast majority of the relationships in this meta-analysis had a strong effect. Additionally, the $95 \%$ confidence interval values also supported these correlation values.

Table 1. Meta-Analytic Result for the Relationships between Trust, Social Presence, Social Support, and Social Commerce Intention

\begin{tabular}{|c|c|c|c|c|c|c|c|c|c|c|c|}
\hline $\begin{array}{c}\text { Independent } \\
\text { variable }\end{array}$ & $\begin{array}{c}\text { Dependent } \\
\text { Variable }\end{array}$ & $\mathbf{k}$ & $\mathbf{N}$ & $\mathbf{r}$ & $\begin{array}{c}\text { Z- } \\
\text { value }\end{array}$ & $\begin{array}{c}\text { P- } \\
\text { Value }\end{array}$ & $\begin{array}{c}\mathbf{9 5 \%} \\
\mathbf{L}(\mathbf{r})\end{array}$ & $\begin{array}{c}\mathbf{9 5 \%} \\
\mathbf{H}(\mathbf{r})\end{array}$ & Strength & Q-test & $\mathbf{I}^{\mathbf{2}}$ \\
\hline Trust in vendor & $\begin{array}{c}\text { Social } \\
\text { Commerce } \\
\text { Intention }\end{array}$ & 13 & 4761 & 0.67 & 13.10 & 0.000 & 0.57 & 0.77 & Strong & $140.540^{*}$ & 91.46 \\
\hline $\begin{array}{c}\text { Trust in Social } \\
\text { Media }\end{array}$ & $\begin{array}{c}\text { Social } \\
\text { Commerce } \\
\text { Intention }\end{array}$ & 18 & 5834 & 0.63 & 12.84 & 0.000 & 0.53 & 0.72 & Strong & $234.330^{*}$ & 92.74 \\
\hline $\begin{array}{c}\text { Emotional } \\
\text { support }\end{array}$ & $\begin{array}{c}\text { Sommerce } \\
\text { Intention }\end{array}$ & 14 & 5044 & 0.49 & 11.85 & 0.000 & 0.41 & 0.57 & Moderate & $111.202^{*}$ & 88.31 \\
\hline $\begin{array}{c}\text { Information } \\
\text { Support }\end{array}$ & $\begin{array}{c}\text { Sommerce } \\
\text { Intention }\end{array}$ & 15 & 5360 & 0.52 & 11.98 & 0.000 & 0.43 & 0.60 & Strong & $138.367 *$ & 89.88 \\
\hline $\begin{array}{c}\text { Social } \\
\text { Commerce } \\
\text { Social Presence }\end{array}$ & 9 & 3098 & 0.45 & 14.93 & 0.000 & 0.39 & 0.51 & Moderate & $21.502^{*}$ & 62.79 \\
\hline
\end{tabular}

In this study, it was assumed that the random effects model needed to be used in combining the effect sizes of different studies. To confirm this preference, a heterogeneity test was carried out. To test the heterogeneity of the data, Q-statistic and $\mathrm{I}^{2}$ values were used for each relationship (Hamari \& Keronen, 2017). In this study, the significance of the Q-statistic values of the paths between the dependent and independent variables means rejection of the no homogeneity hypothesis (Sarkar et al., 2020). Additionally, the $\mathrm{I}^{2}$-value refers to the variance explained with the heterogeneity of the data. The $\mathrm{I}^{2}$-value is in the range of 0-100 (Higgins \& Thompson, 2002). The Q-statistic values in Table 1 were significant on the level of $\mathrm{p}<0.01$, and the $\mathrm{I}^{2}$-values were higher than 62 . As a result, the significance of the heterogeneity tests confirmed the preference of the random effects model.

Finally, publication bias analysis was carried out. In this study, the sequence correlation test was used to analyze publication bias. In this test, the significance of the Tau coefficient was examined to determine whether there was publication bias. When the $\mathrm{p}$ value of the Tau coefficient for each variable in Table 2 
was examined, it was found that it took a value above the 0.05 threshold at the $95 \%$ confidence interval (Dirik \& Yeloğlu, 2020). Therefore, it was concluded that there was no publication bias in this study.

Table 2. Rank correlation test

\begin{tabular}{|c|c|c|c|}
\hline Variable & $\mathbf{k}$ & Kendall's Tau & p-value \\
\hline Trust in vendor & 13 & 0.24 & 0.12 \\
\hline Trust in Social Media & 18 & 0.20 & 0.24 \\
\hline Emotional support & 14 & 0.12 & 0.54 \\
\hline Information Support & 15 & 0.02 & 0.88 \\
\hline Social Presence & 9 & 0,05 & 0.83 \\
\hline
\end{tabular}

\section{Conclusion and discussion}

In this study, a meta-analysis was carried out based on the findings of studies examining the effects of social support, social presence and trust on social commerce intention. Thus, the purpose of this study was to contribute to the literature by synthesizing the findings of previous studies on this topic. Especially social support and trust were divided into their components, and their effects on social commerce intention were examined in detail. Consequently, the proposed hypotheses were confirmed with satisfactory values with the meta-analysis findings.

Mixed results emerged out of previous studies investigating the effects of social support, social presence and trust on social commerce intention. This study aimed to provide useful and practical insights into this topic by combining the findings of previous studies using the meta-analysis method. The most frequently examined predictors of social commerce intention in previous studies were included in this study. It was understood that the hypotheses proposed in this study and the findings obtained as a result of the meta-analysis were compatible.

According to the findings of the meta-analysis, there was a significant and positive relationship between the emotional support on social media platforms and social commerce intention. That is, as the emotional support for consumers increased, consumers' tendencies to shop on social platforms increased. Therefore, the hypothesis H1 was supported. This result supported the findings of previous studies in the literature. The hypothesis $\mathrm{H} 2$ was also supported. That is, the informational support on social media platforms may trigger the social commerce intention of consumers. This finding was similar to those of studies in the literature.

The hypotheses $\mathrm{H} 3$ and $\mathrm{H} 4$ examined the relationship between trust in vendors on social media platforms and social commerce intention. The increased trust of customers in the social media platform increased their intention to shop from the social media platform. Likewise, the increased trust of customers in the vendors making sales on social media platforms triggered their social commerce intentions in the positive direction. Therefore, there was a positive and significant relationship between the trust in social media platforms and vendors on social media and social commerce intention. These findings were compatible with those reported in the literature.

In the hypothesis $\mathrm{H} 5$, the effects of social presence on social media on social commerce intention were tested. According to the meta-analysis findings, there was a directly proportional relationship between the social presence levels on social media and social commerce intention. That is, if the consumer perceived a high level of social presence on social media, their intention to shop in the social ecosystem increased. These findings were compatible with those of previous studies.

\subsection{Theoretical contributions}

The findings of this study present a set of theoretical contributions. This meta-analysis study provided a significant contribution for scientists to see the "big picture" on the topic by synthesizing the findings of studies in the literature on the effects of social support, trust and social presence on social commerce intention. Additionally, the results of this study will allow scientists to make a comparison to their future studies by showing the effect of which antecedent on social commerce intention is greater. Therefore, this study will provide a contribution to a better understanding of the topics of social support, trust, social presence and social commerce intention. 
It was understood that the most important predictor affecting social commerce intention was the trust in the vendors. This shows that the subject from whom the consumer purchases the product themselves is determinant in formation of social commerce intention. These findings revealed the importance of trust for the consumer especially in virtual ecosystems like social media. Furthermore, it was a striking result in the meta-analysis findings that informational support was more effective than emotional support on social commerce intention. This showed that, in shopping activities on social media, rather than emotional support from peers, it was more important for the consumer to obtain quality information on the service or product they would purchase. Social presence on social media affected the social commerce intention of the consumer. However, it was observed that this variable was less effective in comparison to the other variables. This finding showed that social presence was not a primary priority for social commerce intention.

\subsection{Practical implications}

The findings of this meta-analysis study will provide firms and managers who are operating commercial activities on social media with useful inferences regarding the social commerce intentions of customers and certain predictors. As in many studies in the literature, in this study, it was concluded that social support, trust and social presence affected social commerce intention. The conclusion of this study may be more determining than those of single studies in that it revealed the general effect levels in the literature. The findings of this study showed that the trust in the vendors was more effective on the social commerce intentions of the consumer. Therefore, in gaining new customers, development of strategies towards gaining the trust of consumers will contribute to increasing the social commerce intentions of potential customers. Additionally, the finding that the trust in the social media platforms had a significant effect on social commerce intention provides firms with significant advantages. Conduct of commercial activities by implementers on trustable social media platforms may achieve customer trust. What is more, provision of environments that will provide customer trust by social media platforms may have significant contributions to the increase in social commerce.

According to the findings of the meta-analysis, the social support provided from social media platforms had a significant role in the shopping intentions of customers. Therefore, provision of transparent and reliable information regarding the product or service that customers want to purchase by implementers and their encouragement of members of social media communities to provide emotional support may significantly contribute to increasing the social commerce intentions of customers.

\section{Limitations and future research directions}

This study had some limitations. In this study, the relationships between the variables were analyzed by using correlation values. In future studies, meta-analysis may be carried out in the framework of structural equation modelling by using values such as path coefficients and t-statistics. Another limitation was caused by the insufficiency of different types of research. This way because, as shopping operations via social platforms have emerged just recently, empirical studies have not yet reached the desired richness. Future studies may conduct meta-analyses by including more dissertations, manuscripts and other types of academic studies. Furthermore, although there are different antecedents that affect social commerce intention, they could not be included in this study due to the lack of sufficient publications. Future studies may contribute to the literature with a richer variable structure by also including different variables.

\section{References}

Ada, S., Sharman, R., \& Balkundi, P. (2012). Impact of meta-analytic decisions on the conclusions drawn on the business value of information technology. Decision Support Systems, 54(1), 521-533. https://doi.org/https://doi.org/10.1016/j.dss.2012.07.001

Al-Tit, A. A., Omri, A., \& Hadj, T. B. (2020). The driving factors of the social commerce intention of Saudi Arabia's online communities. International Journal of Engineering Business Management, 12, 1847979019899746.

Algharabat, R., Rana, N. P., Dwivedi, Y. K., Alalwan, A. A., \& Qasem, Z. (2018). The effect of 
telepresence, social presence and involvement on consumer brand engagement: An empirical study of non-profit organizations. Journal of Retailing and Consumer Services, 40, $139-149$. https://doi.org/https://doi.org/10.1016/j.jretconser.2017.09.011

Alshibly, H. H. (2015). Customer perceived value in social commerce: An exploration of its antecedents and consequences. Journal of Management Research, 7(1), 17-37.

Ballantine, P. W., \& Stephenson, R. J. (2011). Help me, I'm fat! Social support in online weight loss networks. Journal of Consumer Behaviour, 10(6), 332-337. https://doi.org/10.1002/cb.374

Bianchi, C., Andrews, L., Wiese, M., \& Fazal-E-Hasan, S. (2017). Consumer intentions to engage in scommerce: a cross-national study. Journal of Marketing Management, 33(5-6), 464-494.

Borenstein, M., Hedges, L. V, Higgins, J. P. T., \& Rothstein, H. R. (2011). Introduction to meta-analysis. John Wiley \& Sons.

Bugshan, H., \& Attar, R. W. (2020). Social commerce information sharing and their impact on consumers. Technological Forecasting and Social Change, 153, 119875.

Chen, J., \& Shen, X. L. (2015). Consumers' decisions in social commerce context: An empirical investigation. Decision Support Systems, 79, 55-64.

Cheng, X., Gu, Y., \& Shen, J. (2019). An integrated view of particularized trust in social commerce: An empirical investigation. International Journal of Information Management, 45, 1-12.

Cheung, C. M. K., Chiu, P.-Y., \& Lee, M. K. O. (2011). Online social networks: Why do students use facebook? Computers in Human Behavior, 27(4), 1337-1343.

Cobb, S. (1976). Social Support as a Moderator of Life Stress. Psychosomatic Medicine, 38(5), 300-314.

Coulson, N. S. (2005). Receiving social support online: an analysis of a computer-mediated support group for individuals living with irritable bowel syndrome. Cyberpsychology \& Behavior, 8(6), 580-584.

Dabbous, A., Aoun Barakat, K., \& Merhej Sayegh, M. (2020). Social Commerce Success: Antecedents of Purchase Intention and the Mediating Role of Trust. Journal of Internet Commerce, 1-36.

Dirik, D., \& Yeloğlu, H. O. (2020). Alg1lanan örgütsel politikanın ardılları üzerine ulusal yazın bağlamında bir meta-analiz çalışması. Eskişehir Osmangaži Üniversitesi İktisadi ve İdari Bilimler Dergisi, 15(2), 475-492.

Eriksson, K., Kerem, K., \& Nilsson, D. (2005). Customer acceptance of internet banking in Estonia. International Journal of Bank Marketing, 23(2), 200-216.

Fan, J., Zhou, W., Yang, X., Li, B., \& Xiang, Y. (2019). Impact of social support and presence on swift guanxi and trust in social commerce. Industrial Management \& Data Systems, 119(9), $2033-2054$. https://doi.org/10.1108/IMDS-05-2019-0293

Field, A. P., \& Gillett, R. (2010). How to do a meta-analysis. British Journal of Mathematical and Statistical Psychology, 63(3), 665-694.

Friedrich, T., Schlauderer, S., \& Overhage, S. (2019). Some things are just better rich: how social commerce feature richness affects consumers' buying intention via social factors. Electronic Markets, 1-22.

Fu, S., Xu, Y., \& Yan, Q. (2019). Enhancing the parasocial interaction relationship between consumers through similarity effects in the context of social commerce: evidence from social commerce platforms in China. Journal of Strategic Marketing, 27(2), 100-118.

Fukuyama, F. (1995). Trust: The social virtues and the creation of prosperity (Vol. 99). Free press New York.

Gefen, D., \& Straub, D. (2003). Managing User Trust in B2C e-Services. E-Service Journal, 2(2), 7-24. https://doi.org/10.2979/esj.2003.2.2.7

Gefen, D., \& Straub, D. W. (2004a). Consumer trust in B2C e-Commerce and the importance of social presence: experiments in e-Products and e-Services. Omega, 32(6), 407-424. https://doi.org/https://doi.org/10.1016/j.omega.2004.01.006

Gefen, D., \& Straub, D. W. (2004b). Consumer trust in B2C e-Commerce and the importance of social presence: experiments in e-Products and e-Services. Omega, 32(6), 407-424. https://doi.org/https://doi.org/10.1016/j.omega.2004.01.006

Gibreel, O., AlOtaibi, D. A., \& Altmann, J. (2018). Social commerce development in emerging markets. Electronic Commerce Research and Applications, 27, 152-162.

Gottlieb, B. H., \& Bergen, A. E. (2010). Social support concepts and measures. Journal of Psychosomatic 
Research, 69(5), 511-520.

Hajli, M. (2013). A research framework for social commerce adoption. Information Management \& Computer Security, 21 (3), 144-154.

Hajli, M. N. (2014). The role of social support on relationship quality and social commerce. Technological Forecasting and Social Change, 87, 17-27.

Hajli, N. (2015). Social commerce constructs and consumer's intention to buy. International Journal of Information Management, 35(2), 183-191. https://doi.org/https://doi.org/10.1016/j.ijinfomgt.2014.12.005

Hajli, N., Shanmugam, M., Powell, P., \& Love, P. E. D. (2015a). A study on the continuance participation in on-line communities with social commerce perspective. Technological Forecasting and Social Change, 96, 232-241. https://doi.org/https://doi.org/10.1016/j.techfore.2015.03.014

Hajli, N., Shanmugam, M., Powell, P., \& Love, P. E. D. (2015b). A study on the continuance participation in on-line communities with social commerce perspective. Technological Forecasting and Social Change, 96, 232-241. https://doi.org/https://doi.org/10.1016/j.techfore.2015.03.014

Hajli, N., \& Sims, J. (2015). Social commerce: The transfer of power from sellers to buyers. Technological Forecasting and Social Change, 94, 350-358.

Hajli, N., Sims, J., Zadeh, A. H., \& Richard, M.-O. (2017). A social commerce investigation of the role of trust in a social networking site on purchase intentions. Journal of Business Research, 71, $133-141$. https://doi.org/https://doi.org/10.1016/j.jbusres.2016.10.004

Hamari, J., \& Keronen, L. (2017). Why do people play games? A meta-analysis. International Journal of Information Management, 37(3), 125-141. https://doi.org/https://doi.org/10.1016/j.ijinfomgt.2017.01.006

Higgins, J. P. T., \& Thompson, S. G. (2002). Quantifying heterogeneity in a meta-analysis. Statistics in Medicine, 21(11), 1539-1558.

House, J. S. (1981). Work stress and social support.

Huang, G., Chen, Y., \& Wong, I. (2020). Hotel guests' social commerce intention: the role of social support, social capital and social identification. International Journal of Contemporary Hospitality Management, 32(2), 706-729.

Huang, Z., \& Benyoucef, M. (2015). User preferences of social features on social commerce websites: An empirical study. Technological Forecasting and Social Change, 95, 57-72.

Irshad, M., Ahmad, M. S., \& Malik, O. F. (2020). Understanding consumers' trust in social media marketing environment. International Journal of Retail \& Distribution Management.

Jones, M. A. (1999). Entertaining Shopping Experiences: An Exploratory Investigation. Journal of Retailing and Consumer Services, 6(3), 129-139. https://doi.org/https://doi.org/10.1016/S09696989(98)00028-9

Khan, Z. M. H., \& Shaw, N. (2019). Adding 'Social'to Commerce to Influence Purchasing Behaviour. International Conference on Human-Computer Interaction, 257-273.

Kirca, A. H., Jayachandran, S., \& Bearden, W. O. (2005). Market Orientation: A Meta-Analytic Review and Assessment of its Antecedents and Impact on Performance. Journal of Marketing, 69(2), $24-41$. https://doi.org/10.1509/jmkg.69.2.24.60761

Lal, P. (2017). Analyzing determinants influencing an individual's intention to use social commerce website. Future Business Journal, 3(1), 70-85.

Lauterbach, D., Truong, H., Shah, T., \& Adamic, L. (2009). Surfing a Web of Trust: Reputation and Reciprocity on CouchSurfing.com. 2009 International Conference on Computational Science and Engineering, 4, 346-353. https://doi.org/10.1109/CSE.2009.345

Lee, C.-H., \& Chen, C.-W. (2020). An Empirical Study of Social Commerce Intention: An Example of China. Information, $11(2), 99$.

Leong, L.-Y., Hew, T.-S., Ooi, K.-B., \& Chong, A. Y.-L. (2020). Predicting the antecedents of trust in social commerce-A hybrid structural equation modeling with neural network approach. Journal of Business Research, 110, 24-40.

Leung, W. K. S., Shi, S., \& Chow, W. S. (2019). Impacts of user interactions on trust development in C2C social commerce. Internet Research, 30(1), 335-356. https://doi.org/10.1108/INTR-09-2018-0413

Li, C.-Y. (2019). How social commerce constructs influence customers' social shopping intention? An 
empirical study of a social commerce website. Technological Forecasting and Social Change, 144, 282-294. https://doi.org/https://doi.org/10.1016/j.techfore.2017.11.026

Liang, T.-P., Ho, Y.-T., Li, Y.-W., \& Turban, E. (2011). What drives social commerce: The role of social support and relationship quality. International Journal of Electronic Commerce, 16(2), 69-90.

Liang, T.-P., \& Turban, E. (2011). Introduction to the Special Issue Social Commerce: A Research Framework for Social Commerce. International Journal of Electronic Commerce, 16(2), 5-14. https://doi.org/10.2753/JEC1086-4415160201

Lin, J., Li, L., Yan, Y., \& Turel, O. (2018). Understanding Chinese consumer engagement in social commerce. Internet Research.

Lin, T.-C., Hsu, J. S.-C., Cheng, H.-L., \& Chiu, C.-M. (2015). Exploring the relationship between receiving and offering online social support: A dual social support model. Information \& Management, 52(3), 371-383. https://doi.org/https://doi.org/10.1016/j.im.2015.01.003

Lin, T.-C., Hsu, J. S.-C., Cheng, H.-L., \& Chiu, C.-M. (2012). Exploring Individuals' Loyalty To Online Support Groups From the Perspective Of Social Support. PACIS 2012 Proceedings, 103. https://doi.org/https://aisel.aisnet.org/pacis2012/103

Liu, C., Bao, Z., \& Zheng, C. (2019). Exploring consumers' purchase intention in social commerce. Asia Pacific Journal of Marketing and Logistics.

Liu, Y., Su, X., Du, X., \& Cui, F. (2019). How Social Support Motivates Trust and Purchase Intentions in Mobile Social Commerce. Revista Brasileira de Gestão de Negócios, 21(4), 839-860.

Lu, B., Fan, W., \& Zhou, M. (2016). Social presence, trust, and social commerce purchase intention: An empirical research. Computers in Human Behavior, 56, 225-237. https://doi.org/https://doi.org/10.1016/j.chb.2015.11.057

Lu, B., Zeng, Q., \& Fan, W. (2016). Examining macro-sources of institution-based trust in social commerce marketplaces: An empirical study. Electronic Commerce Research and Applications, 20, 116-131.

Luhmann, N. (1979). Trust. In Trust and Power. Wiley.

Madjar, N. (2008). Emotional and informational support from different sources and employee creativity. Joumal of Occupational and Organizational Psychology, 81(1), 83-100.

Maia, C. R., Lunardi, G. L., Dolci, D., \& D’Avila, L. C. (2019). Competitive price and trust as determinants of purchase intention in social commerce. BAR-Brazilian Administration Review, 16(4).

Makmor, N., Alam, S. S., \& Aziz, N. A. (2018). Social support, trust and purchase intention in social commerce era. Int. J. Supply Chain Manag, 7(5), 572-581.

Morgan, R. M., \& Hunt, S. D. (1994). The commitment-trust theory of relationship marketing. Journal of Marketing, 58(3), 20-38.

Morris, S. B. (2007). Book Review: Hunter, J. E., \& Schmidt, F. L. (2004). Methods of Meta-Analysis: Correcting Error and Bias in Research Findings (2nd ed.). Thousand Oaks, CA: Sage. Organizational Research Methods, 11(1), 184-187. https://doi.org/10.1177/1094428106295494

Naylor, R. W., Lamberton, C. P., \& West, P. M. (2012). Beyond the "Like" Button: The Impact of Mere Virtual Presence on Brand Evaluations and Purchase Intentions in Social Media Settings. Journal of Marketing, 76(6), 105-120. https://doi.org/10.1509/jm.11.0105

Obst, P., \& Stafurik, J. (2010). Online we are all able bodied: Online psychological sense of community and social support found through membership of disability-specific websites promotes well-being for people living with a physical disability. Joumal of Community \& Applied Social Psychology, 20(6), 525-531.

Ommen, O., Janssen, C., Neugebauer, E., Bouillon, B., Rehm, K., Rangger, C., Erli, H. J., \& Pfaff, H. (2008). Trust, social support and patient type-Associations between patients perceived trust, supportive communication and patients preferences in regard to paternalism, clarification and participation of severely injured patients. Patient Education and Counseling, 73(2), 196-204. https://doi.org/https://doi.org/10.1016/j.pec.2008.03.016

Park, H., \& Cameron, G. T. (2014). Keeping It Real: Exploring the Roles of Conversational Human Voice and Source Credibility in Crisis Communication via Blogs. Journalism \& Mass Communication Quarterly, 91(3), 487-507. https://doi.org/10.1177/1077699014538827

Park, N., Kee, K. F., \& Valenzuela, S. (2009). Being immersed in social networking environment: 
Facebook groups, uses and gratifications, and social outcomes. Cyberpsychology \& Behavior, 12(6), 729-733. Pavlou, P. A. (2003). Consumer acceptance of electronic commerce: Integrating trust and risk with the technology acceptance model. International Journal of Electronic Commerce, 7(3), 101-134.

Pratama, M. O., Meiyanti, R., Noprisson, H., Ramadhan, A., \& Hidayanto, A. N. (2017). Influencing factors of consumer purchase intention based on social commerce paradigm. 2017 International Conference on Advanced Computer Science and Information Systems (ICACSIS), 73-80.

Rosenthal, R. (1991). Meta-analytic procedures for social research (Rev. ed). SAGE Publications.

Sarkar, S., Chauhan, S., \& Khare, A. (2020). A meta-analysis of antecedents and consequences of trust in mobile commerce. International Journal of Information Management, 50, 286-301.

Schaefer, C., Coyne, J. C., \& Lazarus, R. S. (1981). The health-related functions of social support. Journal of Behavioral Medicine, 4(4), 381-406.

Schmidt, F. L., \& Hunter, J. E. (2015). Methods of Meta-Analysis: Correcting Error and Bias in Research Findings (Third Edit). https://doi.org/10.4135/9781483398105

Sensuse, D. I., Pratama, A. A., Satria, D., Noprisson, H., \& Ramadhan, A. (2017). Investigating factors of purchase intention based on social commerce, trust and follower in social media. 2017 International Conference on Information Technology Systems and Innovation (ICITSI), 315-319. https://doi.org/10.1109/ICITSI.2017.8267963

Shanmugam, M., Sun, S., Amidi, A., Khani, F., \& Khani, F. (2016). The applications of social commerce constructs. International Journal of Information Management, 36(3), 425-432.

Sharma, S., Menard, P., \& Mutchler, L. A. (2019). Who to trust? Applying trust to social commerce. Journal of Computer Information Systems, 59(1), 32-42.

Sheikh, Z., Islam, T., Rana, S., Hameed, Z., \& Saeed, U. (2017). Acceptance of social commerce framework in Saudi Arabia. Telematics and Informatics, 34(8), 1693-1708.

Sheikh, Z., Yezheng, L., Islam, T., Hameed, Z., \& Khan, I. U. (2019). Impact of social commerce constructs and social support on social commerce intentions. Information Tecbnology \& People.

Shekhar, R., \& Jaidev, U. P. (2020). Antecedents of online purchase intention in the context of social commerce. International Journal of Applied Management Science, 12(1), 68-95.

Shen, J. (2012). Social comparison, social presence, and enjoyment in the acceptance of social shopping websites. Journal of Electronic Commerce Research, 13(3), 198.

Soleimani, M. (2019). The effect of social media quality and social presence on intention towards social commerce with the emphasis on educational services. Journal of Research and Health, 9(5), 454-462.

Tsai, Y.-H., Joe, S.-W., Lin, C.-P., Wang, R.-T., \& Chang, Y.-H. (2012). Modeling the relationship between IT-mediated social capital and social support: Key mediating mechanisms of sense of group. Technological Forecasting and Social Change, 79(9), 1592-1604. https://doi.org/https://doi.org/10.1016/j.techfore.2012.05.013

Wang, C., \& Zhang, P. (2012). The evolution of social commerce: The people, management, technology, and information dimensions. Communications of the Association for Information Systems, 31(1), 105127. https://doi.org/10.17705/1cais.03105

Wang, Yanbo, Min, Q., \& Han, S. (2016). Understanding the effects of trust and risk on individual behavior toward social media platforms: A meta-analysis of the empirical evidence. In Computers in Human Behavior (Vol. 56, pp. 34-44). Elsevier Ltd. https://doi.org/10.1016/j.chb.2015.11.011

Wang, Yichuan, \& Herrando, C. (2019). Does privacy assurance on social commerce sites matter to millennials? International Joumal of Information Management, 44, 164-177.

Wu, J.-J., Chen, Y.-H., \& Chung, Y.-S. (2010). Trust factors influencing virtual community members: A study of transaction communities. Journal of Business Research, 63(9-10), 1025-1032.

Xie, B. (2008). Multimodal computer-mediated communication and social support among older Chinese internet users. Journal of Computer-Mediated Communication, 13(3), 728-750.

Yahia, I. Ben, Al-Neama, N., \& Kerbache, L. (2018). Investigating the drivers for social commerce in social media platforms: Importance of trust, social support and the platform perceived usage. Journal of Retailing and Consumer Services, 41, 11-19.

Yakimova, R., Owens, M., \& Sydow, J. (2019). Formal control influence on franchisee trust and brand- 
supportive behavior within franchise networks. Industrial Marketing Management, 76, 123-135. https://doi.org/https://doi.org/10.1016/j.indmarman.2018.07.010

Ye, S., Lei, S. I., Shen, H., \& Xiao, H. (2020). Social presence, telepresence and customers' intention to purchase online peer-to-peer accommodation: A mediating model. Journal of Hospitality and Tourism Management, 42, 119-129.

Yeon, J., Park, I., \& Lee, D. (2019). What creates trust and who gets loyalty in social commerce? Journal of Retailing and Consumer Services, 50, 138-144.

Zhang, H., Lu, Y., Gupta, S., \& Zhao, L. (2014). What motivates customers to participate in social commerce? the impact of technological environments and virtual customer experiences. Information and Management, 51(8), 1017-1030. https://doi.org/10.1016/j.im.2014.07.005

Zhao, J.-D., Huang, J.-S., \& Su, S. (2019). The effects of trust on consumers' continuous purchase intentions in C2C social commerce: A trust transfer perspective. Journal of Retailing and Consumer Services, 50, $42-49$.

Zhao, Y., Ni, Q., \& Zhou, R. (2018). What factors influence the mobile health service adoption? A meta-analysis and the moderating role of age. International Journal of Information Management, 43, 342-350. https://doi.org/https://doi.org/10.1016/j.ijinfomgt.2017.08.006

Zhao, Y., Wang, L., Tang, H., \& Zhang, Y. (2020). Electronic word-of-mouth and consumer purchase intentions in social e-commerce. Electronic Commerce Research and Applications, 41, 100980. https://doi.org/https://doi.org/10.1016/j.elerap.2020.100980

Appendix 1: Summary of studies used for meta-analysis

\begin{tabular}{|c|c|c|c|c|c|c|}
\hline & Study & Factors & $\begin{array}{l}\text { Method(s) of } \\
\text { analysis }\end{array}$ & $\begin{array}{l}\text { Sample } \\
\text { Size }\end{array}$ & Country & Context \\
\hline 1 & $\begin{array}{l}\text { Bianchi et al. } \\
\text { (2017) }\end{array}$ & $\begin{array}{l}\text { Trust in the } \\
\text { firm's SNS }\end{array}$ & $\begin{array}{l}\text { SEM, Online } \\
\text { survey }\end{array}$ & 1025 & $\begin{array}{c}\text { Chile, } \\
\text { Spain, South } \\
\text { Africa and } \\
\text { Australia } \\
\end{array}$ & $\begin{array}{c}\text { Facebook } / \mathrm{S} \\
\text { commerce }\end{array}$ \\
\hline 2 & $\begin{array}{l}\text { Maia et al. } \\
(2019)\end{array}$ & Trust in vendor & $\begin{array}{l}\text { PLS-SEM, } \\
\text { Online survey }\end{array}$ & 165 & Brazil & $\begin{array}{c}\text { Facebook } / \mathrm{S} \\
\text { commerce }\end{array}$ \\
\hline 3 & $\begin{array}{l}\text { Soleimani } \\
\text { (2019) }\end{array}$ & Social Presence & $\begin{array}{l}\text { PLS-SEM, } \\
\text { Online survey }\end{array}$ & 214 & Iran & $\begin{array}{l}\text { Educational } \\
\text { services } / \mathrm{S}- \\
\text { commerce }\end{array}$ \\
\hline 4 & $\begin{array}{c}\text { Khan \& Shaw } \\
(2019)\end{array}$ & Trust in Vendor & $\begin{array}{c}\text { PLS-SEM, } \\
\text { Online survey }\end{array}$ & 245 & Canada & S-commerce \\
\hline 5 & $\begin{array}{c}\text { Friedrich et al. } \\
(2019)\end{array}$ & Social Presence & $\begin{array}{l}\text { PLS-SEM, } \\
\text { Survey }\end{array}$ & 237 & Germany & S-commerce \\
\hline 6 & $\begin{array}{l}\text { Yeon et al. } \\
(2019)\end{array}$ & $\begin{array}{l}\text { Trust in vendor, Trust in } \\
\text { SNS }\end{array}$ & $\begin{array}{l}\text { CB-SEM, } \\
\text { Survey }\end{array}$ & 323 & Korea & S-commerce \\
\hline 7 & $\begin{array}{l}\text { Sensuse et al. } \\
\text { (2017) }\end{array}$ & Trust in Vendor & $\begin{array}{l}\text { PLS-SEM, } \\
\text { Survey }\end{array}$ & 233 & Indonesia & $\begin{array}{c}\text { Instagram } / \mathrm{S} \\
\text { commerce }\end{array}$ \\
\hline 8 & $\begin{array}{l}\text { Pratama et al. } \\
(2017)\end{array}$ & $\begin{array}{c}\text { Trust in Vendor, Social } \\
\text { Presence }\end{array}$ & $\begin{array}{l}\text { PLS-SEM, } \\
\text { Survey }\end{array}$ & 189 & Indonesia & $\begin{array}{c}\text { Instagram } / \mathrm{S} \\
\text { commerce }\end{array}$ \\
\hline 9 & $\begin{array}{l}\text { Sheikh et al. } \\
\quad(2019)\end{array}$ & $\begin{array}{c}\text { Trust in SNS, Emotional } \\
\text { support, Informational } \\
\text { support } \\
\end{array}$ & $\begin{array}{l}\text { PLS-SEM, } \\
\text { Survey }\end{array}$ & 343 & Pakistan & S-commerce \\
\hline 10 & $\begin{array}{l}\text { Al-Tit et al. } \\
\quad(2020)\end{array}$ & $\begin{array}{c}\text { Trust in SNS, Emotional } \\
\text { support, Informational } \\
\text { support }\end{array}$ & $\begin{array}{l}\text { CB-SEM, } \\
\text { Survey }\end{array}$ & 500 & United Kingdom & $\begin{array}{c}\text { Facebook } / \mathrm{S} \\
\text { commerce }\end{array}$ \\
\hline 11 & $\begin{array}{l}\text { Zhang et al. } \\
\text { (2014) }\end{array}$ & $\begin{array}{c}\text { Social Presence, Emotional } \\
\text { support, Informational } \\
\text { support }\end{array}$ & $\begin{array}{l}\text { CB-SEM, } \\
\text { Survey }\end{array}$ & 1009 & China & S-commerce \\
\hline 12 & Lu et al. (2016) & Trust in Social Media & $\begin{array}{l}\text { PLS-SEM, } \\
\text { Survey }\end{array}$ & 260 & China & S-commerce \\
\hline 13 & $\begin{array}{c}\text { Wang \& } \\
\text { Herrando } \\
(2019) \\
\end{array}$ & Trust in Social Media & $\begin{array}{l}\text { PLS-SEM, } \\
\text { Survey }\end{array}$ & 318 & United States & S-commerce \\
\hline 14 & Hajli (2015) & Trust in Social Media & $\begin{array}{l}\text { PLS-SEM, } \\
\text { Survey }\end{array}$ & 243 & United Kingdom & S-commerce \\
\hline
\end{tabular}


The Effects of Social Support, Trust and Social Presence on Social Commerce Intention: A Meta-Analysis

\begin{tabular}{|c|c|c|c|c|c|c|}
\hline 15 & $\begin{array}{l}\text { Bugshan \& } \\
\text { Attar }(2020)\end{array}$ & Trust in Social Media & $\begin{array}{l}\text { PLS-SEM, } \\
\text { Survey }\end{array}$ & 400 & Asia & s-commerce \\
\hline 16 & $\begin{array}{l}\text { Zhao et al. } \\
(2020)\end{array}$ & Trust in Social Media & $\begin{array}{l}\text { CB-SEM, } \\
\text { Survey }\end{array}$ & 183 & China & S-commerce \\
\hline 17 & $\begin{array}{c}\text { Shekhar \& } \\
\text { Jaidev (2020) }\end{array}$ & Trust in Social Media & $\begin{array}{l}\text { Regression } \\
\text { Analysis, } \\
\text { Survey }\end{array}$ & 267 & India & S-commerce \\
\hline 18 & $\begin{array}{l}\text { Liu et al. } \\
\text { (2019) }\end{array}$ & $\begin{array}{l}\text { Trust in Social Media, } \\
\text { Emotional support, } \\
\text { Informational support }\end{array}$ & $\begin{array}{l}\text { PLS-SEM, } \\
\text { Survey }\end{array}$ & 207 & China & S-commerce \\
\hline 19 & $\begin{array}{l}\text { Liang et al. } \\
\quad(2011)\end{array}$ & $\begin{array}{l}\text { Trust in Social Media, } \\
\text { Emotional support, } \\
\text { Informational support }\end{array}$ & $\begin{array}{l}\text { PLS-SEM, } \\
\text { Survey }\end{array}$ & 411 & Taiwan & S-commerce \\
\hline 20 & Fu et al. (2019) & Trust in Social Media & $\begin{array}{l}\text { PLS-SEM, } \\
\text { Survey }\end{array}$ & 370 & China & S-commerce \\
\hline 21 & $\begin{array}{l}\text { Sharma et al. } \\
(2019)\end{array}$ & Trust in Social Media & $\begin{array}{l}\text { PLS-SEM, } \\
\text { Survey }\end{array}$ & 215 & USA & S-commerce \\
\hline 22 & $\begin{array}{l}\text { Yahia et al. } \\
\text { (2018) }\end{array}$ & Trust in Vendor & $\begin{array}{l}\text { CB-SEM, } \\
\text { Survey }\end{array}$ & 205 & $\begin{array}{c}\text { Golf } \\
\text { Corporation } \\
\text { Council countries, }\end{array}$ & $\begin{array}{l}\text { Instagram/S- } \\
\text { commerce }\end{array}$ \\
\hline 23 & Lal (2017) & $\begin{array}{l}\text { Informational support, Trust } \\
\text { in Social Media }\end{array}$ & $\begin{array}{l}\text { CB-SEM, } \\
\text { Survey }\end{array}$ & 316 & India & S-commerce \\
\hline 24 & $\begin{array}{l}\text { Sheikh et al. } \\
(2017)\end{array}$ & $\begin{array}{l}\text { Emotional support, } \\
\text { Informational support }\end{array}$ & $\begin{array}{l}\text { PLS-SEM, } \\
\text { Survey }\end{array}$ & 310 & Saudi Arabia & S-commerce \\
\hline 25 & $\begin{array}{c}\text { Hajli \& Sims } \\
(2015)\end{array}$ & $\begin{array}{l}\text { Emotional support, } \\
\text { Informational support }\end{array}$ & $\begin{array}{l}\text { PLS-SEM, } \\
\text { Survey }\end{array}$ & 230 & UK & S-commerce \\
\hline 26 & $\begin{array}{c}\text { Lu et et al. } \\
(2016)\end{array}$ & Social Presence & $\begin{array}{l}\text { PLS-SEM, } \\
\text { Survey }\end{array}$ & 546 & China & S-commerce \\
\hline 27 & Hajli (2014) & $\begin{array}{l}\text { Emotional support, } \\
\text { Informational support }\end{array}$ & $\begin{array}{l}\text { PLS-SEM, } \\
\text { Survey }\end{array}$ & 200 & UK & $\begin{array}{c}\text { Facebook/S- } \\
\text { commerce }\end{array}$ \\
\hline 28 & $\begin{array}{l}\text { Chen \& Shen } \\
\text { (2015) }\end{array}$ & $\begin{array}{l}\text { Trust in Social Media, } \\
\text { Emotional support, } \\
\text { Informational support }\end{array}$ & $\begin{array}{l}\text { PLS-SEM, } \\
\text { Survey }\end{array}$ & 376 & China & S-commerce \\
\hline 29 & Li (2019) & $\begin{array}{l}\text { Emotional support, } \\
\text { Informational support, } \\
\text { Social presence }\end{array}$ & $\begin{array}{l}\text { PLS-SEM, } \\
\text { Survey }\end{array}$ & 408 & Taiwan & S-commerce \\
\hline 30 & $\begin{array}{l}\text { Zhao et al. } \\
\text { (2019) }\end{array}$ & $\begin{array}{c}\text { Trust in Vendor, Emotional } \\
\text { support, Informational } \\
\text { support }\end{array}$ & $\begin{array}{l}\text { PLS-SEM, } \\
\text { Survey }\end{array}$ & 206 & China & $\begin{array}{l}\text { WeChat/S- } \\
\text { Commerce }\end{array}$ \\
\hline 31 & $\begin{array}{c}\text { Cheng et al. } \\
(2019)\end{array}$ & Trust in Social Media & $\begin{array}{l}\text { CB-SEM, } \\
\text { Survey }\end{array}$ & 614 & China & Social Commerce \\
\hline 32 & $\begin{array}{c}\text { Hajli et al. } \\
(2017)\end{array}$ & Social Presence & $\begin{array}{l}\text { PLS-SEM, } \\
\text { Survey }\end{array}$ & 201 & & Social Commerce \\
\hline 33 & $\begin{array}{c}\text { Irshad et al. } \\
(2020)\end{array}$ & Trust in Vendor & $\begin{array}{l}\text { CB-SEM, } \\
\text { Survey }\end{array}$ & 574 & Pakistan & Social Commerce \\
\hline 34 & $\begin{array}{l}\text { Fan et al. } \\
\text { (2019) }\end{array}$ & $\begin{array}{c}\text { Trust in Vendor, Emotional } \\
\text { support, Informational } \\
\text { support }\end{array}$ & $\begin{array}{l}\text { PLS-SEM, } \\
\text { Survey }\end{array}$ & 333 & China & $\begin{array}{l}\text { WeChat/S- } \\
\text { Commerce }\end{array}$ \\
\hline 35 & $\begin{array}{l}\text { Lin et al. } \\
(2018)\end{array}$ & $\begin{array}{c}\text { Trust in Vendor, Emotional } \\
\text { support, Informational } \\
\text { support }\end{array}$ & $\begin{array}{l}\text { PLS-SEM, } \\
\text { Survey }\end{array}$ & 511 & China & Social Commerce \\
\hline 36 & $\begin{array}{l}\text { Liu et al. (C. } \\
\text { Liu et al., } \\
\text { 2019) }\end{array}$ & $\begin{array}{l}\text { Social Presence, Trust in } \\
\text { Social Commerce site }\end{array}$ & $\begin{array}{l}\text { PLS-SEM, } \\
\text { Survey }\end{array}$ & 288 & China & Social Commerce \\
\hline
\end{tabular}

